\title{
ANALISIS TERHADAP KUALITAS AIR BAKU SEBAGAI DASAR PERENCANAAN SISTEM PENGOLAHAN AIR SIAP MINUM UNTUK MASYARAKAT
}

\author{
Robertus Haryoto Indriatmoko \& Imam Setiadi \\ Pusat Teknologi Lingkungan, BPPT, Kawasan Puspiptek, Tangerang Selatan, 15314, Indonesia \\ Email:robertus.haryoto@bppt.go.id; imam.setiadi@bppt.go.id
}

\begin{abstract}
ABSTRAK
Dalam merancang sebuah sistem pengolahan air siap minum, peranan hasil analisis kualitas air baku memegang peranan penting dalam menentukan sistem pengolahan air siap minum yang akan dibangun atau dirancang. Kualitas air baku yang ada di SMA Zainul Hassan di desa Genggong, kecamatan Pajarakan, Kabipaten Probolinggo Jawa Timur, memiliki kualitas air tawar, dengan "Total Disolved Solid (TDS)“ $300 \mathrm{mg} / \mathrm{l}$, agak keruh dan belum steril, oleh karena itu dirancanglah sebuah sistem pengalahan air siap minum dengan rancangan terdiri dari 3 bagian yaitu 1. Pengolahan Awal, 2. Pengolahan Ultra filtrasi dan 3. Pengolahan Akhir yaitu Reverse Osmosis (RO) Tawar, Sterilisator dan Pengemasan atau distribusi. Dengan rancangan tersebut maka telah dihasilkan alat pengolahan air yang menghasilkan air bersih dan air siap minum untuk didistrubusikan kepada para user/santri dan masyarakat. Sebelum didistribusikan kepada masyarakat umum mka telah terlebih dahulu dilakukan uji hasil produk sistem pengolahan dsi laburatorium kualitas air, hasilnya adalah uji secara biologi untuk mengetahui kandungan coli dinyatakan steril, sedangkan secara fisik tidak berbau, tak berwarna dan tak berasa, dengan TDS dibawah $100 \mathrm{~g} / \mathrm{l}$ dan secara kimiawi tidak ditemukan unsur yang melebihi batas air minum sehingga dapat disimpulkan bahwa air siap minum hasil pengolahan tersebut layak untuk digunakan sebagai air siap minum.Kesimpulannya adalah sistem pengolahan yang dirancang tersebut layak diginakan untuk mengolah air baku Dari sumber yang telah ditetapkan menjadi air siap minum.
\end{abstract}

Kata Kunci : Air Siap Minum, Sistem Treatmen Air Tawar, TDS, Sistem Osmosa Balik Air Tawar

\section{ANALYSIS OF RAW WATER AS DESIGN BASE OF READY-TO-DRINK WATER TREATMENT SYSTEM FOR THE COMMUNITY}

\author{
Robertus Haryoto Indriatmoko \& Imam Setiadi \\ Center for Environmental Technology, BPPT, Puspiptek Area, South Tangerang, 15314, Indonesia \\ Email: robertus.haryoto@bpt.go.id; imam.setiadi@bppt.go.id
}

\begin{abstract}
In designing a ready-to-drink water treatment sistem, the role of the analysis of raw water quality plays an important role in determining ready-to-drink water treatment sistems to be built or designed. The raw water quality in Zainul Hassan High School in Genggong Village, Pajarakan District, Probolinggo Regency, East Java, has fresh water quality, with "Total Disolved Solid (TDS)" $300 \mathrm{mg} / \mathrm{I}$, rather turbid and not sterile, therefore it is designed a sistem of defeating ready-to-drink water with a design consisting of 3 parts, namely 1. Initial Processing, 2. Processing Ultra filtration and 3. Final Processing namely Fresh Reverse Osmosis (RO System), Sterilizers and Packaging or distribution. With this design, a water treatment device that produces clean water and ready-to-drink water has been produced to be distributed to users / santri and the community. Before being distributed to the general public, it has been tested for the products of the water quality laboratory laboratory treatment sistem, the result is a biological test to find out the coli content is declared sterile, while physically odorless, colorless and tasteless, with TDS below $100 \mathrm{~g} / \mathrm{I}$ and chemically there are no elements that exceed the drinking water limit so that it can be concluded that readyto-drink water is suitable for use as ready-to-drink water. The conclusion is that the designed treatment sistem is feasible to use to treat raw water ready to drink.
\end{abstract}

Keyword: Ready-to-drink, Fresh treatment Sistem, Total Disolved Solid (TDS), Fresh Water Reverse Osmosis. 


\section{PENDAHULUAN}

Untuk merancang sebuah sistem pengolahan air siap minum, analisa terhadap kualitas air baku memegang peranan penting dalam menentukan jenis sistem pengolahan air yang akan dirancang. Oleh karena itu sebelum dilakukan pemasangan sistem pengolahan air dilakukan, maka terlebih dahulu dilakukan survai dasar sebagai tahap awal kegiatan.

Pada tahap tersebut dilakukan kegiatan sampling dan pengenalan lokasi termasuk pendalaman mengenai social kemasyarakatan. Data yang dikumpulkan antara lain :

1. Sumber air (air tanah atau air permukaan atau PDAM) pilih salah satu yang ketersediaannya paling aman.

2. Sumberdaya listrik yang tersedia (PLN, PLTD, Matahari, Genset).

3. Tingkat pendidikan calon operator (STM Listrik, Mesin, SMA, Praktisi). Lokasi Sekolah dapat dilihat pada Gambar 1. Sekolah unggulan SMA Zainul Hassan di desa Genggong, kecamatan Pajarakan, Kabipaten Probolinggo Jawa Timur.

4. Pasar (pengguna atau konsumen) koperasi, masyarakat sekolah, umum).

5. Aksesibilitas terhadap bengkel atau pensuplai komponen dan peralatan. Data pendukung tersebut penting untuk dikumpulkan karena dapat menentukan berhasil tidaknya program tersebut dilaksanakan dilapangan.

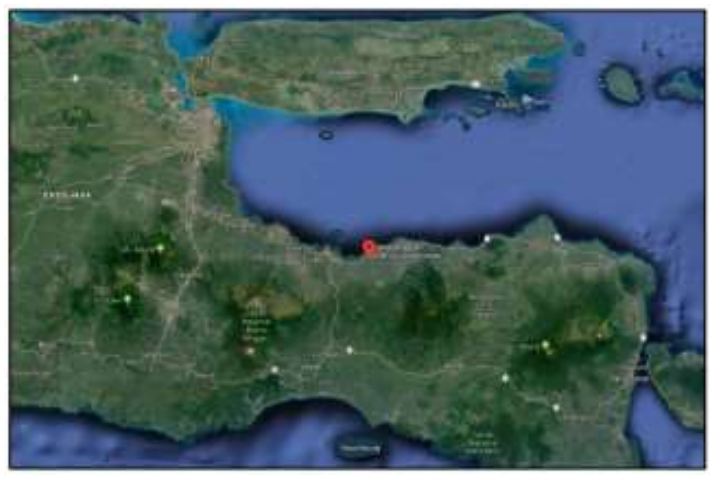

Gambar 1. Lokasi sekolah dalam peta

Survai dasar menyangkut sumber air yang ada menjadi kunci dasar terhadap sistem yang akan didisain. Kualitas air baku akan menentukan jenis pretreatmen yang akan dipilih untuk kualitas air baku tipe keruh jenis pretreatmen yang akan dipilih adalah untuk mengurangi kekeruhan terlebih dahulu misalnya dengan proses koagulasi dan filtrasi.

Hasil survai lapangan adalah untuk sumber air baku yang dapat diandalkan baik pada musim hujan maupun kemarau adalah air dari sumur di sekolah yang bersifat tawar dengan TDS kira-kira 300 ppm, agak keruh dan sifat stereilnya diraguan. Oleh karena itu perlu dilakukan pretreatmen penghilang keruh. Untuk jenis kualitas air baku yang sifat pencemarannya mengarah ke pencemaran organik maka jenis pre treatmen yang dipilih adalah pretreatmen untuk memperbaiki kualitas air baku dari pencemaran organik terlebih dahulu. Oleh karena itu jenis air baku semacam ini sangat layak digunakan sebagai air baku air siap minum.

Jenis pretreatmen yang akan dipakai juga dapat menentukan besar kecilnya biaya yang akan digunakan untuk mengolah air. Ketersediaan sumber daya listrik di lokasi terpasang adalah sangat penting. Sumber listrik merupakan komponen utama untuk menggerakkan pompa baik pompa air baku, pompa dosing, pompa aerasi, pompa tekanan tinggi dan pompa produksi. Jika dilokasi terdapat sumber listrik PLN atau PLTD maka perlu disiapkan jaringan penghubung untuk sumber listrik tersebut. Sedangkan jika tidak terdapat sumber listrik maka perlu disiapkan sumber listrik dari generator set atau tenaga matahari.

Ketersediaan sumber listrik yang ada dapat mempengaruhi dalam hal pemilihan jenis pompa yang akan digunakan, jenis pompa AC atau DC. Operator memegang peranan penting dalam keberhasilan mengoperasikan sistem secara keseluruhan. Keberhasilan disini bukan hanya dapat mengoperasikan atau menjalankan peralatan akan tetapi dapat mengoperasikan dengan benar dan dapat pula memberbaiki kerusakan/mengetahui jenis kerusakan dan tahu harus membawa kemana jika sistem atau peralatan mengalami kerusakan.

Operator alat pengolah air siap minum paling tidak harus mempunyai pengetahuan dasar permesinan dan kelistrikan, tersedia dilokasi tersebut. Disamping operator keberhasilan pengoperasian sistem ini juga harus ditunjang oleh tenaga administrasi dan pemasaran. Juga ada dilokasi tersebut.

Tim administrasi bertanggung jawab terhadap pengadministrasian mulai dari pencatatan produksi sampai dengan pembayaran untuk biaya penggantian alat dan perbaikan sistem termasuk juga listrik. Satu lagi dan ini menjadi ujung tombak dari produksi yang dihasilkan yaitu control terhadap kualitas produksi dan pemasaran. Terkait dengan tugas dari tim pemasaran yaitu mencari pasar yang kompeten. Semua yang sudah diperlukan sudah di survai dilokasi, pada survai pendahuluan ini.

Pasar atau pengguna merupakan muara dari suatu produk yang dihasilkan, disinilah terjadinya penyerapan produksi dan pengguna. Jika pasar atau pengguna tersebut telah terjadi maka tugas selanjutnya yang penting dilakukan adalah bagaimana menjaga hubungan agar pasar tersebut tidak lari ke produsen yang lain. Penting untuk diperhatikan adalah kelangsungan dan ketersediaan produksi yang dibutuhkan oleh pasar.

Ketepatan dalam pemenuhan kebutuhan atau kecukupan produksi harus dijaga dengan baik, pasar jangan sampai menunggu, produk harus selalu tersedia dengan jumlah yang cukup dan tidak boleh 
sampai terjadi kekosongan produksi. Faktor ke lima yang juga sangat penting untuk menjaga kelangsungan produksi agar selalu tersedia di stok adalah keberlanjutan dari kinerja sistem pengolahan air yang tidak boleh terganggu karena adanya kerusakan sistem secara keseluruhan.

Untuk menunjang kinerja tersebut perlu didukung oleh kesiap sediaan tenaga service/bengkel dan aksesibilitas atau kemudahan dalam daya jangkau dengan bengkel terdekat. Setiap kerusakan yang terjadi harus dapat diatasi dengan cepat melalui home service. Untuk pengadaan peralatan atau komponen yang didatangkan dari lokasi yang jauh atau diluar kota perlu dijalin kerjasama dengan supplier peralatan atau komponen secara on line.

Cara online ini akan memudahkan kita dalam pengadaan peralatan yang diperlukan. Sistem pengolahan air siap minum ini disiapkan untuk pemenuhan kebutuhan air minum untuk wilayah yang belum tersedia atau ada akses air bersih yang saat ini sedang disediakan oleh pemerintah.

Seperti diketahui bahwa akses masyarakat akan air bersih sedang ditingkatkan. Menurut sumber dari dari Kementerian PUPR Direktur Jenderal Cipta Karya Kementerian PUPR Danis H Sumadilaga mengungkapkan, akses air bersih seluruh masyarakat Indonesia baru mencapai 72 persen hingga akhir 2018 lalu. "Sampai 2018 akses kita sekitar 72 persen. Kalau tahun 2019 diperkirakan akses air bersih baru 77 persen, jadi masih 23 persen menuju 100 persen," ujar Danis di kantor Kementerian PUPR, Jakarta, Jumat (1/3/2019). https://properti.kompas.com/read/2019/0 3/01/165719621/meleset-dari-target-akses-air-

bersih-baru-72-persen. Akses terhadap air bersih melalui program yang disebut hibah air minum perkotaan dan pedesaan tersebut akan terus ditingkatkan hingga mencapai 73,6 \%. Kehadiran sistem pengolahan air bersih siap minum yang dirancang dengan mendasarkan pada kualitas air baku ini salah juga cocok jika akan digunakan untuk mengolah air siap minum yang berasal dari air baku air bersih yang diproduksi oleh sistem yang dihasilkan dari produksi air bersih tim PUPR, hal ini disebabkan karena produk air bersih yang dihasilkan dikatakan telah memenuhi standar air untuk air bersih.

Sistem yang dirancang dengan menggunakan alat ini akan meningkatkan kualitas air bersih menjadi air siap minum karena diproses menggunakan sistem saringan ultra filtrasi dengan kemampuan 0,1-0,01 micron dan dikombinasikan dengan saringan dengan menggunakan membrane RO dengan kemampuan 0,001-0,0001 micron.

Dengan menggunakan alat ini maka kombinasi dari kedua membrane semi permeable tersebut akan mampu menyaring koloid, turbidity (kekeruhan), suspended solid (zat padat terlarut), bakteri dan virus. Adanya kombinasi penyaringan ini maka produk air bersih yang dihasilkan akan dapat digunakan sebagai produk air siap minum.

\subsection{Ruang Lingkup}

Kegiatan ini dimulai dengan survai lapangan untuk mencari potensi kualitatif dan kuantitatif terhadap sumber air baku untuk menentukan jenis teknologi pengolahan air yang akan dirancang.

Koordinator terdiri dari Ir. P Nugro Rahardjo, M.Sc dan Imam Setiadi, S.Com, didampingi dan diterima oleh staf SMA UNGGULAN ZAINUL HASAN Sekolah dalam hal ini adalah Kepala sekolah dan berberapa staf jajaran di sekolah tersebut. Para pendamping dari pihak sekolah antara lain adalah: (Lihat Gambar 2): 1. Mohammad Inzah, M.Pdl Kepala Sekolah 2. Abdullah, SHI - Waka Humas \& Sarana Prasana 3. Mohammad Yusuf Nasyruddin, S.Pd - Guru 4. M. H. Ainul Yaqin, S.Si.

Sistem pengolahan awal dilakukan dengan membagi sistem pelolahan air siap minum menjadi 4 sistem yaitu pengolahan awal, tengah, akhir dan sistem distribusi hasil. Pada sistem pengolah awal yang dilakukan adalah penolahan air baku sistem yang dirancang adalah menyiapkan airbaku mengolah air baku dengan cara mengoksidasi air baku dengan cara memberikan oksidasi dengan $\mathrm{KMnO}$ (kallium permanganate) menggunakan sistem injeksi pompa dosing. Hasilnya disaring dengan menggunakan pompa makro filter dengan media berupa pasir, mangan zeolite dan karbon active.

Tahap kedua dari proses ini dilanjutkan dengan pengolahan dengan menggunakan pengolahan ultra filtrasi yang dimulai dengan filtrasi air baku dengan menggunakan micro filtrasi bak/kantong filter sebelum di proses dengan ultra filtrasi. Hasil dari proses ini adalah air baku yang sudah tersaring dengan filter sampai 0,01 mikron.

Tahap ketiga adalah pengolahan dengan menggunakan sistem RO. Alat yang digunakan adalah pompa tekanan tinggi dan penyaring $\mathrm{RO}$ dengan membrane semipermeable hasilnya adalah air hasil pengolahan yang sudah tersaring dengan kapasitas 0,001-0,0001 micron. Jernih, TSD rendah, streril dan siap minun.

Tahap keempat adalah penampungan hasil, pendistribusian dan pemasaran hasil yang terlebih dahulu dimulai dengan pelatihan terhadap operator tentang cara operasi, service alat dan pemasaran hasil.

\subsection{Tujuan Dan Sasaran}

Tujuan utama dari pengolahan air siap minum adalah :

1. Untuk mendisain sistem pengolahan air secara typical yang didasarkan atas keberadaan air baku baik dari sisi kualitas dan kuantitas air baku yang ada di lokasi terpasang. 
2. Untuk meningkatkan kualitas air di wilayah terpasang, sehingga dapat diolah menjadi air siap minum.

3. Untuk medapatkan air bersih yang masih dapat digunakan sebagai air bersih sebagai produk sampingan dari air reject atau buangan dari penyaring ultra filtrasi baik digunakan sebagai air bersih maupun air tambahan lair baku yang masih dapat diolah kembali.

4. Untuk memenuhi kebutuhan akan air minum bagi wilayah yang tidak/belum dapat fasilitas pengolahan air bersih dalam program PUPR.

\section{METODOLOGI}

Bahan dan alat yang digunakan sebagai dasar pengolahan ini antara lain : air baku, material tangki, pipa pvc, pompa, alat listrik, asssesoris, filer, ultra filtrasi, komponen RO, tangki produksi, sumber daya yang tersedia, kabel, kontrol panel, perangkat manajemen dan user atau pemakai.

Air baku ini akan sangat menentukan jenis pengolahan yang akan dirancang, apakah sistem pengolahan air asin, asam atau tawar. Pengukuram sumber air melakui survai lapangan yang dilakukuan melalui pengukuran langsung dan analisis di laboratorium. Analisis langsung juga dilakukan ke sumber air, ketersediaan dan sistem distribusinya.

Setelan survai langsung dan analisis laboratorium diperoleh hasil maka dilakukan: Perancangan alat sesuai hasil laboratorium maka dimulai dengan perencanaan gambar dan perakitan alat dengan pengelasan, untuk pembuatan sistem panel control dilakukan dengan pembuatan sistem pretreatment, pengolahan awal, perakitan pengolahan ultra filtrasi, pengolahan reverse osmosis, dan pereakitan sistem tersebut menggunakan skit atau frameserta pengiriman ke lokasi dan perakitan atau instalasi di lapangan Uji coba dan Pelatihan terhadap operator serta manajerial peralatan untuk operasional.

\section{HASIL DAN PEMBAHASAN}

Sistem pengolahan air siap minum dirancang seperti Gambar 2.

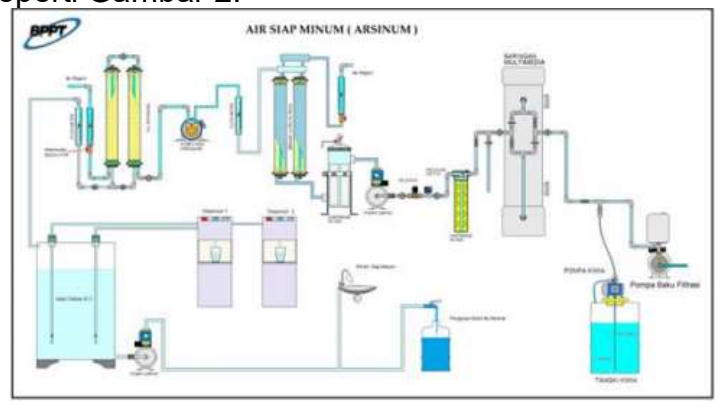

Gambar 2. Rangkaian Sistem Pengolahan Air Siap Minum di SMA Zainul Hassan di desa Genggong, kecamatan Pajarakan, Kabipaten Probolinggo Jawa Timur.
Sistem kelistrikan digambar dengan disain sebagai berikut: Sistem ini mengontrol kinerja dari peralanan seperti high pressure pump untuk RO dan system automatic, termasuk control high pressure pump, sumber listrik untuk dispenser dan ultra violet. Sistem kelistrikan secara lengkap dapat dilihat pada Gambar 3.

Otomatisasi secara off dari system ini dapat terjadi jika.1. Air baku kurang atau hampir habis. 2. Jika terjadi kekurangan tekanan pada system ultrafiltrasi misalnya tekanan air kurang dari 2 bar dan tekanan operasi pompa tekanan tinggi kurang dari 2 bar dan lebih dari 15 bar. Jika Level air lebih tingginya atau kurang dari level yang ditentukan. Pada tangka dispenser. 3. Level produksi pada tangki SS penampung melebihi atau kurang yang dilevel pada level tangka produksi yang ditentukan. Juga akan off secara automatic.

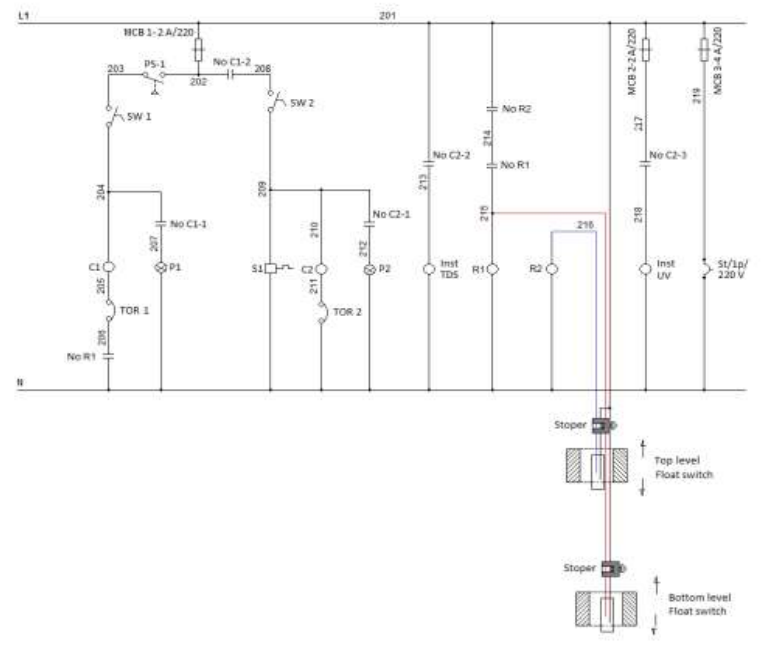

Gambar 3. Sistem kelistrikan untuk Kontrol Panel Ultra Filtrasi dan RO

Pengolahan air siap minum dimulai dari pengambilan air baku kemudian diolah dengan kombinasi oksidasi filtrasi makro, miri filtrasi, filtrsi ultra filtrasi dan filtrasi membrane simi permeable dan disribusi ke tingkat user serta system manajemen.

Sistem pengolahan air siap minum yang dibangun tertdiri dari 4 sistem yaitu:

1. Pengolah tingkat awal yng memiliki peralatan terdiri dari system control yang berguna untuk mengontrol air baku, sistem oksodasi basi, mangan dan kekeruhan. Air baku yang msih mengandung kelarutan besi dan mangan dioksidasi dengan $\mathrm{KMnO} 4$ atau kalium permanganate agar zat besi dan mangan dapat diendapkan dan disaring menggunakan filter sand, mangan zeolite dan carbonactive agar dapat dikurangi kadarnya dalam air baku sehingga sesuai dengan kriteria desain dari air baku agar kadar besi dan mangan ada dibawah 0,1 ppm dan air baku menjadi bersih, tidak berwarna dan tidak berbahu. 
2. Pada tahap ke dua pengolahan didesain dengan menggunakan alat ultrafiltrasi. Yaitu menggunalan filter ultrafiltrasi sebagai alatnya. Tekanan operasi alat adalah maximum dengan 2 bar. Debit yang dihasilkan oleh ultra filtrasi ini minimal sama dengan debit yang dihasilkan untuk mensuplay debit RO. Kekurangan jumlah debit untuk memproduksi RO dapat menyebabkan kerusakan yang dimulai dengan kavitasi debit antara ultra filtrasi da pompa RO. Akan berepengaruh pada jumlah air siap minum yang dihasilkan. Tekanan naik air pada ultra filtrasi dan debit RO berkurang. Pengolahan dengan menggunakan ultra filtrasin akan menghasilkan air bersih dengan tingkat penyaringan dengan kekeruhan ada dibawah 0,01 micron. Air bersih yang dihasilkan sangat bagus sebagai input dari system RO.

3. Tahap ke tiga yaitu penyaringan pada tingkat membran semipermeable yaitu tingkat RO. Alat yang penting disini adalah pengatur tekanan masuk untuk $\mathrm{RO}$ dan keluar $\mathrm{RO}$ alat ini mengontrol pompa tekanan tinggi jika tekanab operasi kurang dari 10 bar maka pompa tidak hidup dan jika tekanan lebih dari pompa tekanan tinggi RO misalnya max 15 bar pompa juga tidak akan hidup. Produk yang dihasilkan dari system ini adalah air siap minum dengan tingkat filtrasil 0,001 micron, steril, TDS rendah, dengan $\mathrm{Ph}$ asam biasanya $\mathrm{pH} 5$ dan ini akan dinaikkan sampai pH 6 atau 7 dengan penambahan mineral misal korosex (Magnesium oxide) sehingga layak minum.

4. Tahap keempat yaitu merupakan tahap penampungan dan tahap produksi dimana sistem pengolahan ditambahkan tempat untuk memproduksi air hasil pengolahan tahap ketiga dan alat untuk mendistribusikan hasil pengolahan kepada masyarakat atau user. Sterilisasi hasil produksi dijaga dengan pemasangan lampu ultra violet. Lampu ini dasamping sebagai sterilisator tabung juga berguna untuk sterilisator hasil produksi atau penampungan di botol galon, supaya hasil produksinya tetap terjaga dari pencemaran dan tidak berbau.

Keempat tahap tersebut merupakan tahap penting dalam produksi, agar diperoleh hasil yang optimal dalam proses produksi. Selanjutnya ada tahap yang juga penting untuk di lakukan agar distribusi hasil dapar dinikmati user adalah tahap pemasaran. Tahap ini dimulai dari bagaimana mengenal user secara lebih baik. Hal yang penting dilakukan di tahap ini adalah:

1. Menjaga kualitas produksi. Artinya adalah hasil produksi yang terjaga, mutu, atau kualitas produksi, dan kebersihan, aman dan nyaman.

2. Melayani pasar yaitu: selalu ada di pasaran meskipun jumlah produksinya terbatas jangan sampai ada stoke yang kosong. Syukur-syukur sebagai pengusaha mau menjemput bola. Memberikan produksi atau hasil produksi air siap minum pada masyarakat yang membutuhkan.

Hasil analisis terhadap produksi pengolahan menggunakan air baku yang berasal dari air tanah dari lokasi terpasang telah dimanfaatkan menjadi air siap minum.

\section{KESIMPULAN DAN SARAN}

Setelah dilakukan proses pengolahan air siap minum yang menggunakan system pegolahan mulai dari air baku yang berasal dari air sumur yang tadinya tidak layak minum karena TDS cukup besar sampai 300 ppm, kurang jernih/agak keruh dan tidak steril maka setelah diaplikasikan alat pengolah air sap minum maka masyarakat di SMU dan sekitarnya telah dapat menikmati air siap minum secara praktis.

Berdasar kegiatan tersebut dapat ditarik kesimpulan bahwa:

1. Air sumur dapat dimanfaatkan sebagai air baku dasar yang digunakan sebagai air siap minum.

2. Biaya pengolahan air dapat lebih efifien dari sisi waktu dan uang. Jika tadinya harus kehilangan waktu untuk memanaskan air, dan tenaga panas dari kompor, sekarang dibutuhkan waktu yang singkat. Sekarang masyarakat dengan mudah menggunakan teknologi untuk memperoleh air yang steril.

3. Ikut mensukseskan program pemerintah, makin banyak masyarakat yang memperoleh akses yang mudah terhadap air siap minum.

4. Melalui proses pengolahan ini disamping diperoleh air siap minum sebagai produk utama, dapat diperoleh juga produk sampingan berupa air bersih yang dapat digunakan sebagai air bersih untuk berbagai keperluan yang berasal dari air reject ultra filtrasi.

5. Menghasilkan Produk Air Siap Minum Kapasitas 15 Liter per Menit, TDS menjadi 63,6 ppm dari sekitar 300 ppm, bersifat Steril dan Siap minum.

Sebagai pelaksana kegiatan, yang terlibat langsung dan untuk ketrampilan dalam kegiatan tersebut perlu dilakukan seperti training kegiatan terhadap operator dan manajerial.

\section{PERSANTUNAN}

Disampaikan Terima Kasih kepada Bapak Direktur Pusat Teknologi Lingkungan yaitu Dr Ir Rudi Nugroho, M.Eng. Karena penulis Boleh terlibat Aktif dalam sosialisasi program kegiatan yang dilakukan dalam rangka Layanan Teknologi Teknologi Air Bersih dan Limbah Cair yaitu Konstruksi Pengolahan Air Berbasis Masyarakat. Dalam Inovasi Teknologi Air dan Sampah Berbasis Masyarakat yaitu Sebuah 
Program Yang Merupakan Stuktur Pekerjaan Teknologi Lingkungan, yang dilakukan malalui Pusat Teknologi Lingkungan, BPP Teknologi.

\section{DAFTAR PUSTAKA}

1. Departemen Kesehatan RI, 2010. Peraturan Menteri Kesehatan No. 492 Tahun 2010 tentang Persyaratan Kualitas Air Minum

2. https://properti.kompas.com/read/2019/03/01 /165719621/meleset-dari-target-akses-airbersih-baru-72-persen.

3. Indriatmoko, R H dkk, 2007, Penyediaan Air Siap Minum Pada Situasi Tanggap Darurat Bencana Alam, Jurnal Air Indonesia, ISSN 0216-4140, BPPT Jakarta.
4. Said, Nusa Idaman., 2008., Teknologi Pengolahan Air Minum, Pusat Teknologi Lingkungan Badan Pengkajian dan Penerapan Teknologi, Jakarta

5. Said, Nusa Idaman.,2007, Pengolahan Air Minum Dengan Karbon Aktif Bubuk, Jurnal Air Indonesia, Vol 3, No2, ISSN 0216-4140, PTL, Jakarta

6. Yudo, Satmoko dkk., 2010, Pemilihan Teknologi Daur Ulang Limbah Domestik Perkantoran, Jurnal Air Indonesia, ISSN 0216-4140, PTL, Jakarta 


\section{LAMPIRAN}

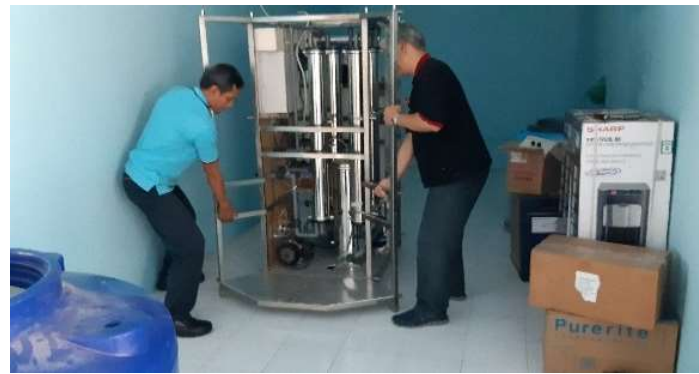

a)Instalasi Ultra Dan Ro Filtrasi

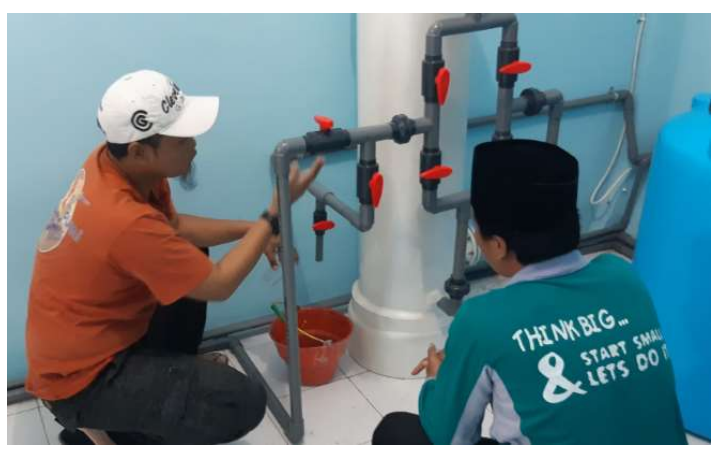

c)Pelatihan Multi Media

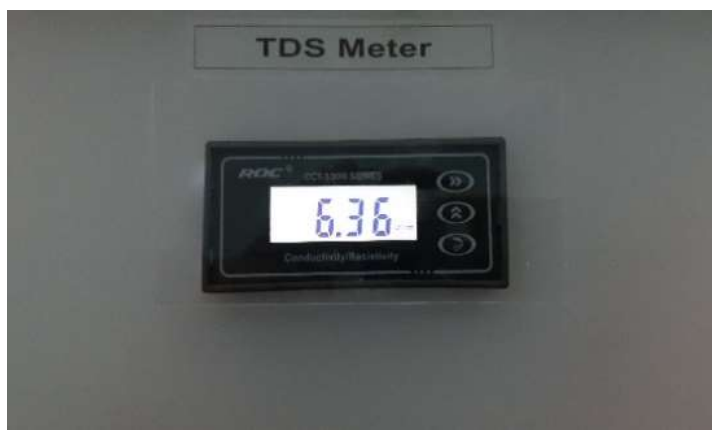

e)Tds Produksi

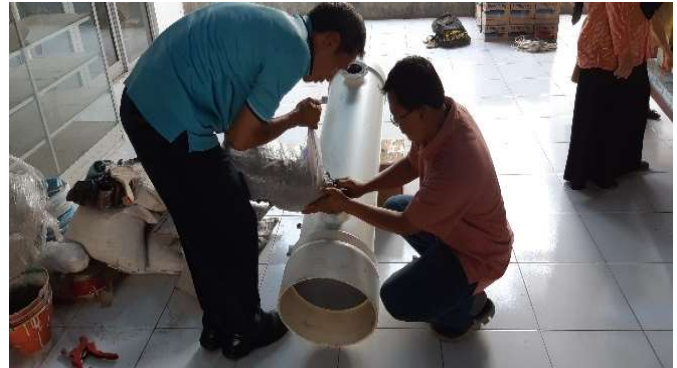

b)Pemasangan Filter Multi Media

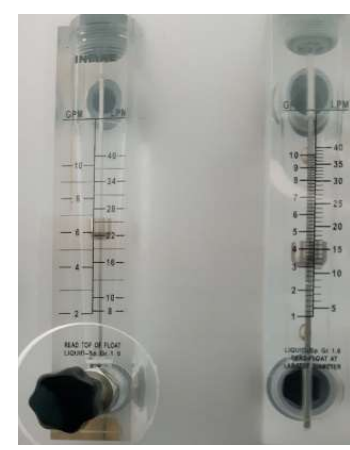

d)Debit Produksi Ro

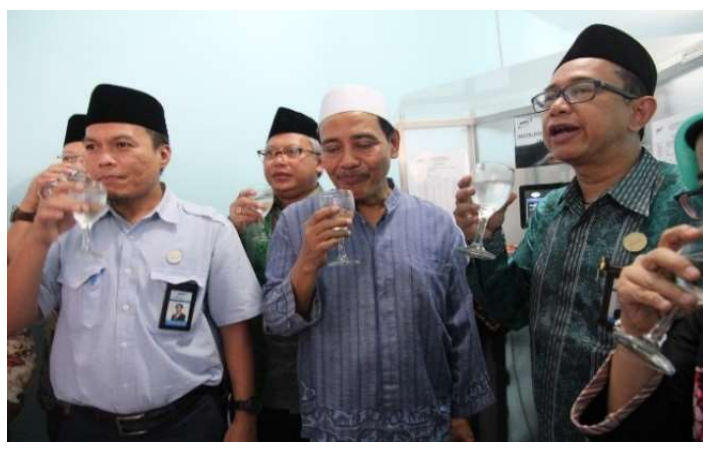

f)Peresmian

Gambar 4. Aktifitas di SMA Zainul Hassan di desa Genggong 